\title{
サンマの卵，仔稚魚の打上げ獘死
}

\author{
多部田修・塚原博 \\ (1967 年 10 月 30 日受理)
}

\section{On the Mass Mortality of Eggs and Larvae of Pacific Saury Caused by Stranding in Northern Kyushu}

\section{Osame TaBeTa and Hiroshi Tsukahara*}

Every cold season the fish and other organisms are stranded upon some beaches along the Tsushima Current. Of these, the egg and larva of Pacific saury, Cololabis saira (Brevoort), are ones of the most numerous forms. To make clear the destruction of this fish by stranding, the authors observed the phenomenon every morning in the seasons of 1964 1967 at the beach (1.5 km length) of Shingu, northern Kyushu (Fig. 1).

The results obtained are as follows:

(1) The eggs of Pacific saury were found from the end of November to the end of January (Fig. 2), and the larvae, from the beginning of December to the end of March (Fig. 7). These eggs and larvae were supposed to have been originated from the southward migrating fish in our waters.

(2) Besides on the some floating Sargassum, the main spawning bed of the fish (Fig. 3 and 4), the eggs were found being attached on the materials from the land (Table 1). They were considered to have been spawned in the inshore waters, which was also supported by the evidence in the developmental stages of the collected eggs (Fig. 5).

(3) In the highest peak the number of stranded eggs was estimated to amount to 15 millions a day, and that of larvae to over 1,000 individuals. These were recorded distinctively just after the prevailing northwester and cold (Fig. 6 and 10).

(4) The stranded fish range from 6 to $87 \mathrm{~mm}$ in total length, accounting the larvae less than $20 \mathrm{~mm}$ for over $90 \%$ of all fish (Fig. 8 and 9). The natural mortality of the fish caused by this phenomenon occur in both the egg and the larva stages mainly less than $20 \mathrm{~mm}$.

(5) This phenomenon was recognized on the beaches along the Tsushima Current in the spawning season of the southward migrating population (Fig. 1). It may be, hence, considered that the offsprings of the southward migrating population are sometimes destroyed in enormous quantities by this phenomenon in our waters.

対馬水道付近のサンマ Cololabis saira (Brevoort) については一般に2つの来遊群が認められる。すな わち，10１1 月に山口県沖に現われ，11 12 月に壱岐近海を経て五島付近に達する南下群と，4〜 5に 壱岐北方で散見され，5６月に山口県見島沖，島根県沖へ去る北上群とである ${ }^{1,2)}$ 。た，これらの各水域

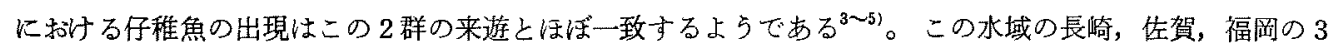
暴においてはサンマは沿岸の定置种や流し刺網によつて年間約 1000 トンが漁萑され机，とくに長崎罧の壳 伎地方ではサンマ漁業が重視されている。

筆者らは 1964 年以来, 北部九州の沿岸に推いて，冬季に海岸八打上げられる魚類その他の調査を行なつ ている7。この調査において海岸へ打上げられた多数のサンマの畉, 仔稚魚を観察し, 対馬水道域のサンー について若干の生態的知見を得たので報告する。

\footnotetext{
* 九州大学農学部水産学教室 (Fisheries Laboratory, Faculty of Agriculture, Kyushu University, Fukuoka, Japan).
} 
材料

調查は主として北部九州の福岡市郊外新宮海岸 で行なつた (Fig. 1)。この海岸は津屋陭まで続く 砂浜の一部で，西北を向いている。調査の区間に はこのらちの約 $1.5 \mathrm{~km}$ の砂浜を選んだ。このほ か新宮に隣接した海岸や传賀〜新潟県にいたるい くつかの海岸でも観察した。この調查は 1964 年 秋に始められ，現在る継続中であるが，とくに下 記の期間には新宮の調查区間に批いて毎朝観察し た。(1) 1965 年 1 月 10 日 5 月 10 日 (1965 年冬季々呼ぶ），(2) 1965 年 12 月 1 日 1966 年 5 月 30 日 (1966 年冬季), (3) 1966 年 10 月 18 日 1967 年 4 月 30 日 (1967 年冬季)。これら 以外の期間には月に 3 4 回の観察を行なつた。 調查時には調査区間の砂浜へ打上げられた卵，仔 稚魚数をすべて記録することに努め，また打上げ が大量に沶よんだ場合はその一部を採集して全量 を推定した。卵の一部は実験室へ持婦つて睬化実験を行なつた。なお，打上げ現象と気象との関連を調べる ために福岡気象台の資料を用いた。

結果

卵の打上げ時期, 打上げの範囲 調査した 3 期間について卵の打上げは 1965 年冬季には 12 月 13 日〜 1 月 13 日，1966 年冬季には 12 月 31 日 1 月 29 日，1967 年冬季には 11 月 21 日 1 月 15 日に新 宮で観察された。そのうち非常に大量の打上げがあつた 1967 年冬季の旬別打上げの変化をみると (Fig. 2), 11 月下旬が最も多く, その後 1 月中旬まで逐次減少している。卵の打上げは 1965 年 12 月の調查におい, て, 新宮之同様に志賀, 津屋崎, 勝浦 (Fig. 1) でも確認された。

産卵基盤, 付着卵数, 卵の状態 サンマは流れ藻その他の浮漂物に卵を産みつけ, 卵は綑絡系によつて 付着している ${ }^{5,8,9)}$ 。今回の調査においても海藻に産みつけられたものが多かつたが (Fig. 3, Table 1)，松 の葉, わら繩, サランネット片などにも付着が欢られた。海藻のらちではオオバモク, ヤッマタモク,ショ 口モク等が多く, これらはこの海域の海藻群落の普通の成員である ${ }^{10)}$ 。また, これらの産卵基盤となつた海 藻は 5 25 cm にら切れて海藻片となつたものが大多数で，これらはその切断面などから判断するとすでに

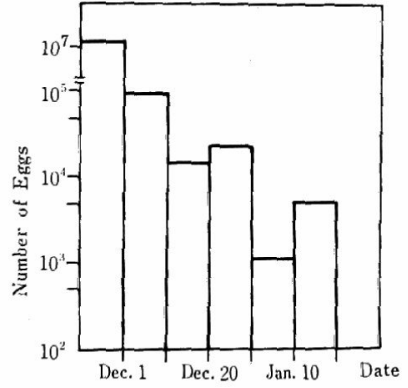

Fig. 2. Number of collected eggs summed for every 10 days period in 1966 1967.

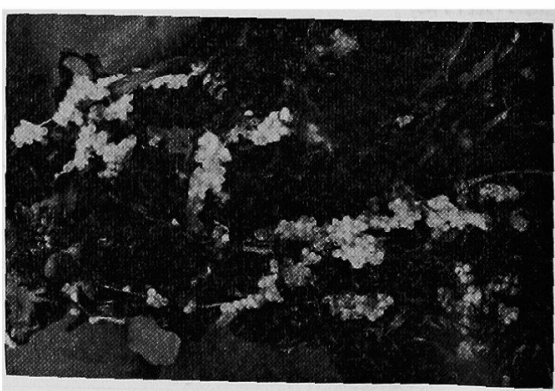

Fig. 3. The stranded eggs of Pacific saury, entangling with Sargassum. 
Table 1. Spawning bet of Pacific saury observed on November 22, 1966 (134 cases).

\begin{tabular}{|c|c|c|}
\hline \multicolumn{3}{|c|}{ Sargassums } \\
\hline (1) & Sargassum ringglodianum & 31 \\
\hline (2) & S. patens & 27 \\
\hline (3) & Cystophyllum sisymbrioides & 23 \\
\hline (4) & C. turneri & 13 \\
\hline (5) & Sargassum fulvellum & 9 \\
\hline (6) & S. piluliferum & 8 \\
\hline (7) & S. tortile & 6 \\
\hline (8) & S. serratifolium & 6 \\
\hline (9) & S. hemiphyllum & 2 \\
\hline (10) & S. thunbergii & 1 \\
\hline (11) & S. horneri & 1 \\
\hline (12) & S. confusum & 1 \\
\hline \multicolumn{3}{|c|}{ Others } \\
\hline (1) & Zostera marina & 2 \\
\hline (2) & Leaves of pine tree & 2 \\
\hline (3) & Straw rope & 1 \\
\hline (4) & Saran net & 1 \\
\hline
\end{tabular}

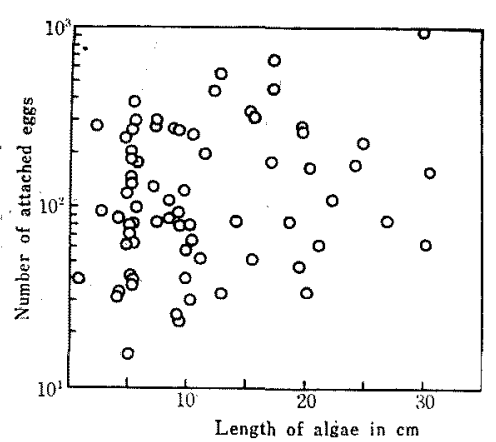

Fig. 4. Relation between the length of algae fragment and the number of attached eggs.

流れ藻としてかなりの日数を経過していると思 われた。付着卵は 1 つ海藻に数十〜数千粒に およんだが，多くは上述の海藻片に50〜300 粒 の卵塊としてついていた (Fig. 4)。

卵山肧体形成初期より餒化直前にいたる各発 生段階のむのを含み, 垺出後の卵款も認められ

た(Fig. 5)。これらの卵は検鏡の結果大多数のものが正常に発生していると認められたが，打上げ畉を研究 室に持䚻つて飼育実験（3回）を行なつたところいずれも睬化にはいたらなかつた。

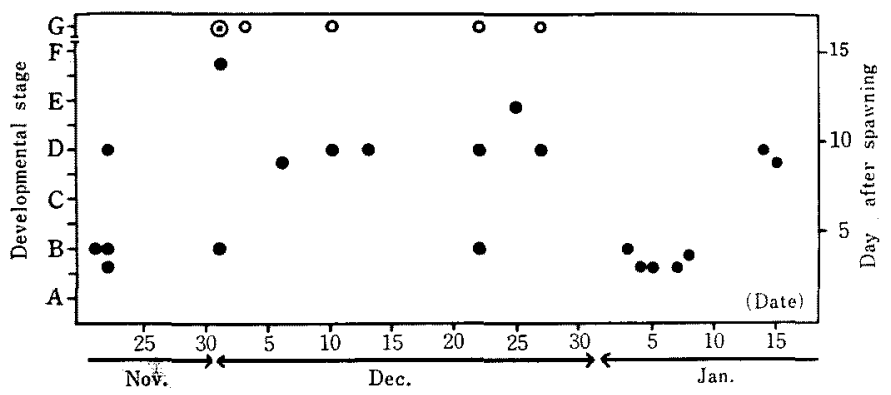

Fig. 5. The developmental stages of eggs collected during the cold season of 1966 1967. The marks are as follows; (A) blastula stage, (B) embryo with ca. 40 myotomes, (C) embryo with chromatophores on the yolk sac, (D) embryo with the tail reaching the occipital region, (E) embryo turned over $1 \frac{1}{2}$ in its chorion, (F) shortly before hatching, and $(\mathrm{G})$ shortly after hatching. (YUSA ${ }^{13)}$, and HotTA and FuKUSHIMA ${ }^{14)}$ ). The symbols are; - egg, $\odot$ newly hatched larva, and $\bigcirc$ egg sac after hatching.

卵の打上げ量, 打上げの条件調查期間の 1965 年冬季には推定約 23.5 万粒, 1966 年冬季には 7.5 万 粒の打上げ卵を観察しただけであるが，1967 年冬季には 1,550 万粒以上の卵を記録した。1967 年冬季の 卵の大部分は 11 月 22 日に観察されたもので，その朝には干潮時の砂浜一面に前述の海藻片についた卵塊 が散在し，満潮 千潮線間（幅 $10 \sim 20 \mathrm{~m}$ ) の $1 \mathrm{~m}$ 長さ当りに平均 80 塊，10,200 粒 ( 5 回測定の平均)の 


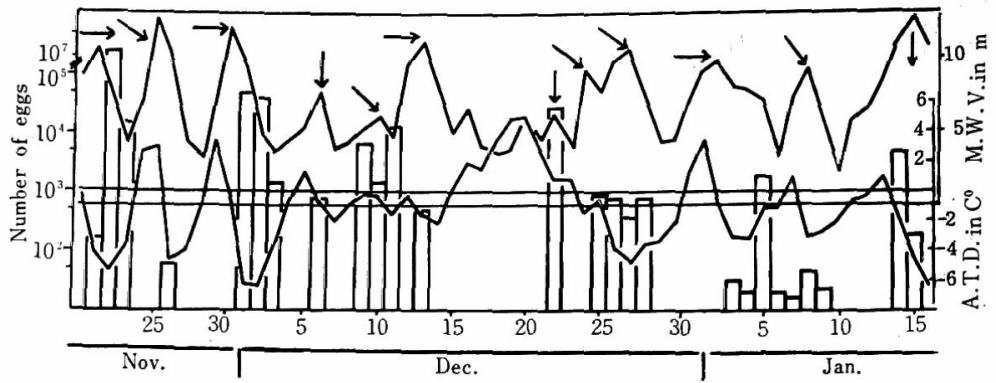

Fig. 6. Relation between the egg-stranding and the environmental conditions in 1966 1967. M. W. V., maximum wind velocity; A. T. D., deviation of air temperature from the standard level; arrow shows the wind direction; these were observed at Fukuoka City. Standard temperature used is obtained from the data of the daily average temperature in $1956 \sim 1965$.

卵が認められた。この数值から調査区間の $1.5 \mathrm{~km}$ で約 1,530 万粒，同様の打上げが確認された新宮〜古 賀の約 $4 \mathrm{~km}$ の砂浜で約 4,000 万粒の卵が打上げられたと推定される。な拉, 冬季にこの海岸へ打上げら れるソデイカを採取する漁業者によれば，この上らな魚卵の大量打上げは例年観察されるとのことである。 卵の打上げと天候との関連をみるために Fig. 6 K 1967 年冬季の 1 日每の観察卵数と気温, 風速拉よび風 向との関係を示した。この図からサンマの卵は西〜北寄りの風が強く, 気温が低い日に打上げられる傾向が 認められる。

仔稚魚の打上げ時期，打上げの範囲仔稚魚の打上げは 1965 年冬季には 1 月 15 日〜3 月 10 日， 1966 年冬季には 12 月 1 日 3 月 25 日，1967 年冬季には 12 月 1 日 3 月 15 日の各期間に観察された。 最も大量にみられた 1966 年冬季の出現をみると (Fig. $7 \mathrm{~A}), 12$ 月後半に最大を示し, その後減少して1 月後半に再び多くなる。 2 月後半 3 月前半には出現せず， 3 月後半になつてわずかに打上げられた。この

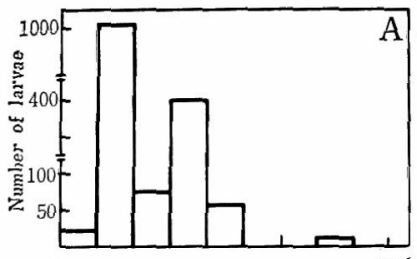
ように 2 3 月にほぼ 1 力月の打上げ休止期があり, その後に数個 体が出現するという傾向は調查した各シーズンに共通している。仔 稚魚の打上げ範囲については 1966 年 1 月に西日本の各地で調査し, 佐賀県唐津市から島根県出雲大社市にいたるいくつかの海岸でその

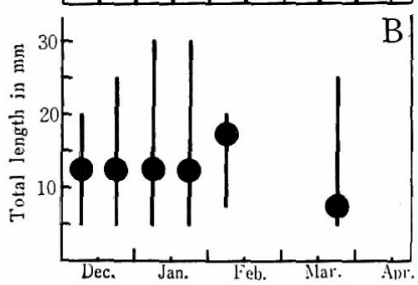

Fig. 7. Number of collected larvae summed for every half month period in $1965 \sim 1966$ (A), and their total length composition (B). Solid circle indicates the mode.

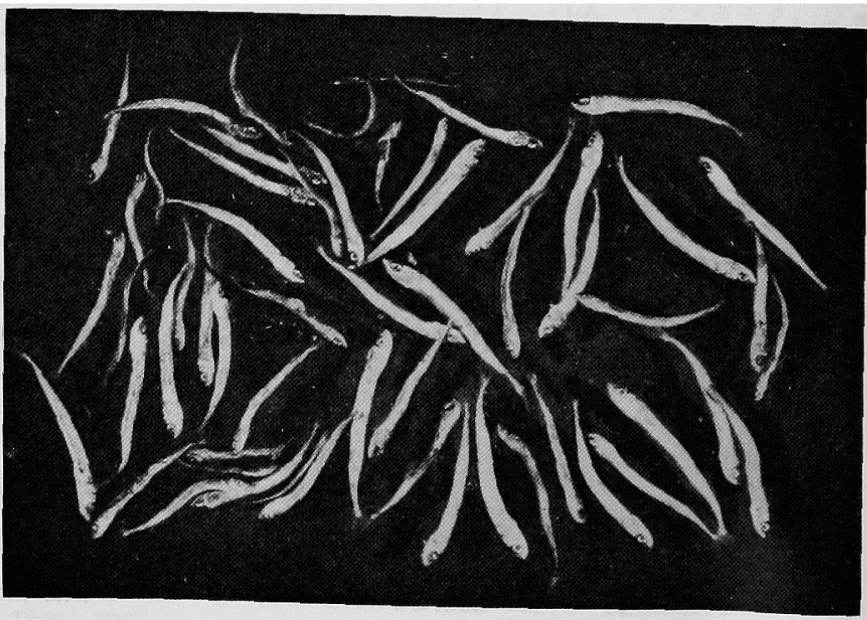

Fig. 8. The stranded larvae of Pacific saury (natural size), 
打上げを確認した (Fig. 1)。

仔稚魚の状怎, その大きさ 仔稚魚は死んで発 見されるものが多いが，打上げ直後の生きたるのも みられた (Fig. 8)。これらは冬季には一般に 3〜4 時間は砂の上や海藻の中に残されている。しかし， 気温が上昇すると1時間ぐらいで腐敗消失するか， またはガンマルス等によつて食われてしまうことが 観察された。なお，1965 年 12 月埰集した 15 個 体の仔魚 $(10 \sim 20 \mathrm{~mm})$ の消化管内容物調査では食 物は認められなかつた。この3シーズンに測定した 仔稚魚 820 個体の全長組成を Fig. 9 亿示した。打 上げられた倠魚は全長 6 87 mm で, とくに 10 $\sim 20 \mathrm{~mm}$ のものか $90 \%$ 以上を占めた。全長組成 は季節的に大きな変化はないが (Fig. 7 B), 1965 年 3 月には $70,87 \mathrm{~mm}$ の 2 個体が打上げられ，1966 年 12 月には烰化直後の仔魚がその時採集された他 の魚に付着していたこともある。

仔稚魚の打上げ数, 打上げの条件＼cjkstart新宮の調査区間において 1965 年冬季には 29 個体，1966 年冬季に は 2,000 個体以上，1967 年冬季には 50 個体の仔稚魚と数十個体の脬化直後の仔魚をそれぞれ観察した。最 も大量に打上げられた 1966 年冬季の1日毎の観察個体数をFig. 10 に示した。このシーズンに括いては総 観察個体数の約 50\% の仔稚魚が 12 月 16 日に打上げられ，この朝には多いところで $1 \mathrm{~m}$ 間隔の波打際 に平均 10 個体の仔稚魚を数えた。な沶，仔稚魚は卵塊と異なり，小さいために発見が困難であつたり，打 上げ後短時間で消失することもある。したがつて，これらの調查期間には各年々も上述の個体数をはるかに 上をわる数量の仔稚魚が打上げられたと思われる。仔稚魚の打上げと天候との関係をみると(Fig. 10), 卵の 場合と同様に西〜北寄りの風が強く, 気温が低下した日に顕著な打上げ現象が生じている。

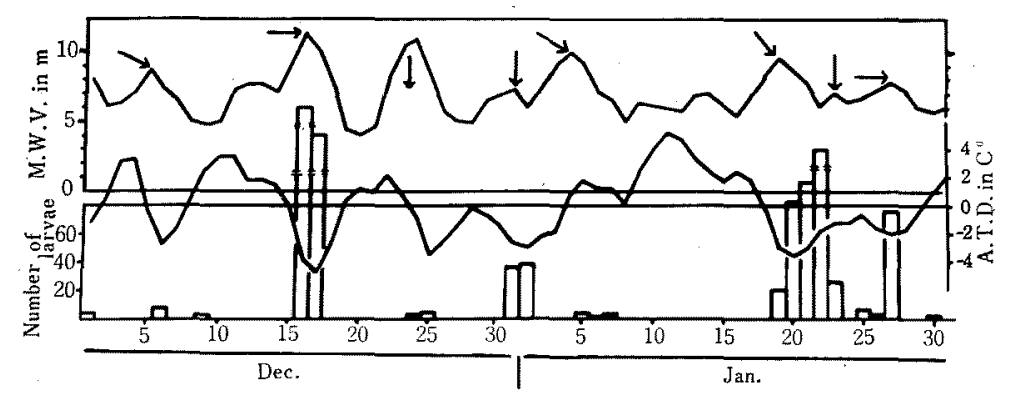

Fig. 10. Relation between the larva-stranding and the environmental conditions in 1965 1966. M. W. V., maximum wind velocity; A. T. D., deviation of air temperature from the standard level; arrow shows the wind direction; these were observed at Fukuoka City. Standard temperature used is obtained from the data of the daily average temperature in 1955 1964 .

\section{考察}

魚卵が風波などによつて海岸へ大量に打上げられ，擎死することはニシン ${ }^{11) ， サ ョ リ 1^{12)} に つ い て す て ゙ に ~}$ 報告されている。また，青森，秋田，新潟県などの海岸では冬季に八タハタの卵塊が大量に打上げられ 
Table 2. Catch of Pacific saury with set and drift nets by Hakozaki Fisheries Co-operative Association, Iki Island.

(ton)

\begin{tabular}{c|r|r|r|r|r|r|r|r|r|r}
\hline Year & Oct. & Nov. & \multicolumn{1}{c|}{ Dec. } & Jan. & Feb. & Mar. & Apr. & May & Jun. & \multicolumn{1}{c}{ Total } \\
\hline $1960 \sim 61$ & & 73,413 & 228,041 & 50,236 & & & 22 & & & 351,690 \\
$1961 \sim 62$ & 3,970 & 15,627 & 156,564 & 9,126 & 22,176 & 5,954 & 4,416 & 72 & 196 & 218,101 \\
$1962 \sim 63$ & 1,913 & 1,226 & 5,998 & 64 & & 40 & & & & 9,241 \\
$1963 \sim 64$ & 11,675 & 1,048 & 11,056 & 176 & & & 10 & 36 & & 24,001 \\
$1964 \sim 65$ & & 14,901 & 17,107 & 24,520 & 7,260 & 2,550 & & & & 66,338 \\
$1965 \sim 66$ & 5,315 & 20,819 & 171,656 & 83,957 & 11,060 & 10 & & & & 292,817 \\
$1966 \sim 67$ & & 17,304 & 10,173 & 1,534 & 275 & & & & & 29,286 \\
\hline
\end{tabular}

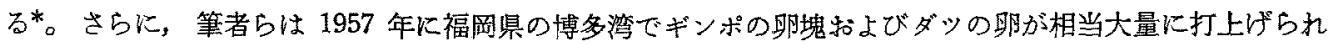

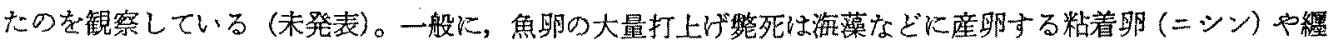

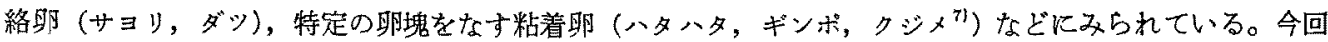
筆者らが観察したサンマの眀の打上げは前者の例に属する。

今回の調查では畉は 11 月下旬 1 月下旬，仔稚魚は 12 月上旬 3 月下旬に打上げられた。この時期の

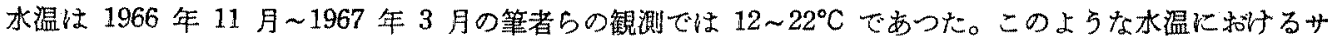

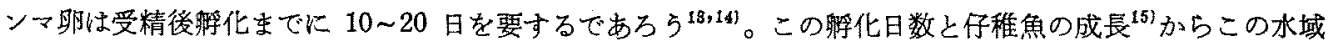

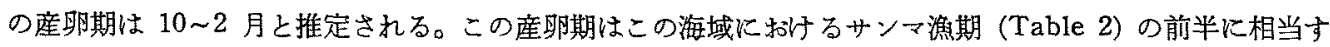
る。すなわち，水温降下期に拁ける南下群の産畉期" に当つている。な拈，北上群の通過期と思われる 4 6月の調查では眆，稚仔魚の打上げを確認することはできなからた。

サンマの産郋基盤としては流れ藻などの浮漂物が大いに利用されるが，この海域に拊るる産卵期にはホン ダワラ類の生育は顕著でなく，したがつて流れ藻の少ない時期であるといわれる゙ ${ }^{10)}$ 。しかし，今回の調查で は打上げ藻が比較的大量に認められ，打上げ卵の付着基盤の错察 (Table 1, Fig. 4) からサンマは主として 流れ藻に産卵したと思われる。また，前述のようにホンダワラ類以外の陸上からの浮漂物にも楽の付着がみ られ (Table 1)，それらの卵が発生初期であつたこと（Fig. 5) お上びこの海域に淤るる冬季の流れ藻の分 布 ${ }^{16)}$ 中標識流れ藻, 漂流瓶の放流実験の結果 ${ }^{16,17)}$ などから, 壱岐東水道よりも沿岸域で産卵が行なわれたと 考光られる。

新宮〜古賀の $4 \mathrm{~km}$ ほどの砂浜で，1966 年 11 月に 1 日に約 4,000 万粒の㽗の打上げが妿つたと推定さ

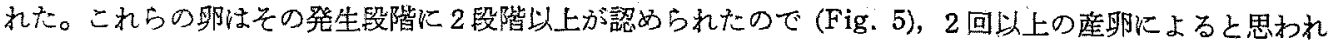
るが，この産畉親魚は体長約 $30 \mathrm{~cm}$ (体重 $100 \mathrm{~g}$ ) で 1 回に 2,000 粒を放畉するとすれば'15,18)，4,000 万粒 の畉は約 2 万個体（2トン）の雌に由来することになる。は，これらの畉は長さ $5 \sim 25 \mathrm{~cm}$ の海藻片に付 着して打上げられたものが多く(Fig. 4)，去のよらな海藻片になる過屋では非常に多くの卵塊が海底沈下 したであろう。したがつて、この期にはかなりの産卵群が来遊，産卵していたことが考えられる。

打上げられた仔稚魚は全長 $30 \mathrm{~mm}$ 以下の個体が大多数で, とくに $20 \mathrm{~mm}$ 以下のものが $90 \%$ 以上を占 めた。すなわち，風波，温度低下などの環境条件の変化によるサンマの自然死亡は，全長 $20 \mathrm{~mm}$ 以下の仔

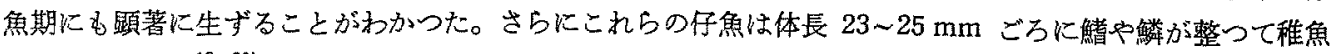
期へ移行するが ${ }^{18 \sim 20)}$ ，稚魚にもかなりの自然死亡が認められた (Fig. 8，9)。

打上げの卵，估稚魚数は年による変動が大きく，卵の多い年には仔稚魚も多いという関係は認め難い。 た，打上げ量はこの近海に淤る漁獲量 (Table 2)の年変動とむ関連は認められないよらである。打上げの

*西海区水産研究所技官三尾真一博士扰よび九州大学農学部附属水産実験所古市政幸氏のご教示汇よる。 両氏に暗意を表する。 
期間については卵，估稚魚の打上げ量の多いシーズンは多少その期間が長い傾向はあるが，その傾向もそれ ほど顕著なるのではない。打上げ量は Fig. 6,10から判断すると，むしろそのシーズンに掓る畉，仔稚 魚の分布と冬季の季節風によつて大きく影響されているであ万う。

以上のようにサンマの卵，俰稚魚の打上げ現象は対馬䐘流に沿つた西日本の各地の沿岸で観察され，時に はそれらの打上げが大量におよぶこともある。ひとたび打上げられた卵，仔稚魚はほとんどが死減するであ ろらからこの近海に就る冬季の打上げによるサンマ卵，仔稚魚の損失は大きいと推定される。

この研究にあたり海藻の種查定と助言の労をとられた沢田助教授, 調查に協力された教室の方くに謝意を 表する。

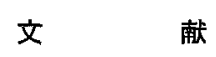

1）山口外海水試：1３2（プリント)，(1954).

2) 藤川政文: 舆崎水試資料 No. $82,63 \sim 70$ (1956).

3) 内田恵太郎・道津喜衛: 対馬暖流開発調查報告, 第 2 輯, $3 \sim 65$ (1958).

4) 深滝 弘: 日本海区水研報, No. 7, 17 42 (1959).

5）川口哲夫：本誌，31，799 803 (1965).

6) 農林省: 昭和 $36 \sim 40$ 年漁業恶殖業生産統計年報, 憹林統計協会, 東京 (1963 1967).

7) O. Tabeta and H. Tsukahara: This Bull., 33, 295 302 (1967).

8) 内田恵太郎： 海洋の科学, 1, 132 139 (1941).

9) 木村喜之助玉加: 東北、水研報, No. 12, 28 48 (1958).

10) 瀬川宗吉活か：九大譨学芸誌，17，83 89 (1959).

11）田村 正ほか：瞹化場試験報告, 6, 11 26 (1951)，8，95 107 (1953).

12）千田哲資：日生熊会誌，16，171 175 (1966).

13) T. YUSA: Bull. Tohoku Reg. Fish. Res. Lab., No. 17, $1 \sim 14$ (1960).

14）堀田秀之・福島信一：東北区水研報, No. 23, 61 72 (1963).

15）堀田夸之：東北区水研報， No. 11，47 64 (1958).

16) 瀬川宗吉ほ加：九大農学芸誌，19，125 134, 135 140 (1961).

17) 野中 進: 福岡水陚研報, No. 2, 1 26 (1962).

18) M. Hatanaka: Tohoku J. Agr. Res., 4, $227 \sim 269$ (1955), $313 \sim 340$ (1956).

19）小迲 繁： 東北区水研報，No. 11，38 46 (1958).

20) 内田恵太郎注加：日本産魚類の稚魚期の研究，第 1 集, viii +89 , 九州大学農学部水産学第 2 教室, 福岡 (1958). 